\title{
Factors Affecting Food Price Inflation in Pakistan
}

\author{
Abdul Ghafoor Awan ${ }^{1 *}$, Muhammad Imran² \\ ${ }^{1}$ Dean, Faculty of Management and Social Sciences, Institute of Southern Punjab, 9-KM, Bosan Rd, \\ Multan, PAKISTAN \\ ${ }^{2}$ M Phil Scholar, Department of Economics, Institute of Southern Punjab, 9-KM, Bosan Rd, Multan, \\ PAKISTAN \\ *Corresponding Contact: \\ Email: ghafoor70@yahoo.com \\ Cell Phone: 092313-6015051
}

\begin{abstract}
Food Price inflation an economic challenge in global world. The objective of the study is to examine the demand pull and cost push variables that affect food prices inflation. We use time series annual data from 1980-2013. Data is generated from various issues economic survey of Pakistan and world development indicators. We applied ADF test, Johansen's co-integration technique, and VECM to analyze the long term and short run relationship between the variables. The result obtained from double log model explores that most significant demand pull and cost push variables are fertilizer prices, fuel prices, money supply, per capita GDP, and foreign aid which are positively related with food prices while exchange rate is inversely related with food prices in Pakistan. The error correction model is also statistically significant and shows that market forces play an active role in restoring long-run equilibrium.
\end{abstract}

Keywords: Food Price Inflation, Johansen's co-integration, Fuel Prices, Fertilizer Prices, Money Supply, Per capita GDP, Foreign Aid

How to Cite: Awan AG and Imran M. 2015. Factors Affecting Food Price Inflation in Pakistan ABC Journal of Advanced Research, 4, 75-90.

This article is is licensed under a Creative Commons Attribution-NonCommercial 4.0 International License.

Attribution-NonCommercial (CC BY-NC) license lets others remix, tweak, and build upon work non-commercially, and

although the new works must also acknowledge \& be non-commercial.

\section{INTRODUCTION}

Continuous rise in food prices is a big challenge for policy makers at global level. Pakistan has not been out of danger from the negative consequences. Being a developing country Pakistan is also facing challenges of prices in food sector. It is the bigger task to control the food item prices. Increase in food prices needs a great attention because it decreases the welfare of the poor households (Quentin Wodon et al., 2008: World Bank 2008).There are different views about the causes of food inflation. Economists argue that the extra finance by Govt. through creating of new money is the cause of food inflation (Monetarist) but the second party Govt. argues that structural changes and international effect is the main cause of food inflation. Awan et al (2015) says that food inflation is a common 
phenomenon in Pakistan because government continues to increases prices of essential commodities. Awan and \& Waqas (2014) contended that one of main problem of developing countries are high inflation which has made the lives of common man miserable. Awan \& Jabbar (2014) plead that governments in the developing countries is forced to increase the prices of agriculture products because of the involvement of feudal involvement in the policy-decision making. Awan (2015) argues that inflation has multidimensional effect, which is felt from a child to an old person because it equally affect low and fixed income and particularly those who have no source of income.

UN Inter-agency assessment mission on impact of food crisis in Pakistan (2008), reported that high food inflation in Pakistan create malnutrition problems which create low productivity, increase health care cost and create wasting (low weight for height) problem in growing children. The increasing prices in food switched the poor households to low quality (less nutritional) items which create social unrest and health related issues. Higher food prices decrease the budget of the consumer for the education and transportation. So, the ratio of the dropout from school is increasing (Hamid Salman et al: 2014).

During the period of 1972-2008 food inflation was 9.9 percent and during 1997-2003 it was less than 10 percent in Pakistan. After 2003 it started to increase and reached up to 12.5 percent in 2004-05. It was 17.5 percent in 2007 and 26.6 percent in 2008. This Sharpe increase in food inflation was due to shortage of wheat, supply shortage create huge increase in prices of meat, milk, oil and vegetables. A rise in international prices of food items with the prices of oil was also a big reason for food inflation in Pakistan (Government of Pakistan, Economic Survey 2007, 2009, 2013). This food inflation is really a serious issue for policy makers. According to ADB study a 10 percent increase in food prices because about 2 percent increase in poverty ratio. Many monetary and fiscal measures were taken to reduce food inflation but it still stood at double digit. When food prices rises sharply it become a big challenge for policy makers to control the factors because a number of structural, demand and supply side factors are involved. Among others, these factors also playing adverse role as money supply, exchange rate, foreign aid, input prices and transportation cost. According to Hamid Salman et al (2014) energy prices and exchange rate is playing a dominant role to push up the food prices in Pakistan. The present study is intended to sort out the main factors of food price inflation in Pakistan.

Pakistan food inflation is triggered by the factors: expansionary monetary and fiscal policy, petroleum prices, supply shocks and support prices (Muhammad Abdullah, 2009). Food inflation hurts growth and it reduces the purchasing power of households (saqib, world Bank). So, being the dangerous enemy of the economy it is needed to investigate the root cause of the problem and trace out the factors which push up the food prices because if basic necessity as the staple food is out of the reach of poor households it will affect on the malnutrition which leads to low productivity in the economy.

This study will help us to determine what the real causes of food inflation are while it is local or foreign effect which creates food inflation and what is the role of individual variables in the food inflation phenomenon. There are demand pull and cost push factors which create food inflation. As it is one harmful factor for economy, it is important to understand and identify the causes of inflation (Mally Likukela 2007). 


\section{REVIEW OF EMPIRICAL STUdies}

Several studies have examined the factors affecting food prices. One study was made by Chad Hart and John Lawrence (2006) examined the factors affecting U.S food prices. Time series data from 1950 to 2000 were used. They analysis showed that farmer receive only 19 cent of every dollar spent on food products, remaining 81 cents are other cost like transportations, packing and labor. Their study founded that 80 percent of the increase in the food price is outside the farm gate. However energy prices and other input prices push up the food inflation inside the farm gate. In USA and Europe higher crude oil prices increases the price of food. They recommended the use of bio-fuel technology for lower cost.

Philips C. Abbott et al (2011) concluded that five factors behind the rising food prices in USA. First factor was demand shocks they investigated corn export to china and domestic demand of bio-fuels production increased the demand which push up the prices. Second was hoarding to take the advantage of future price rise, third is adverse weather condition, fourth Chinese policy of stock also effect on the world market since last four years, import policy of China in case of soybean and other products rises the prices in USA. Fifth factor is exchange rate.

Ashley Crawley et al (2011) examined the high food prices and downfall of economies especially Arab countries. They used time series data from 2001 to 2010 for analysis. Researchers included explanatory variables GDP per capita, income inequality and political condition (authoritarian or democracy) in the model. Their finding showed that food inflation was high in the authoritarian economies like Syria, Egypt, and Tunisia while democracy had negative effect on food inflation. Christopher Adam et al (2012) assessed the food price inflation in Tanzania. They used time series data from 2002 to 2011 for their assessment. The result showed that factors as supply shocks, fuel prices, storage, monetary policy, and exchange rate were responsible for recent food inflation in Tanzania.

Jema Haji and Fekadu Gelaw (2012) described the determinants of food inflation in Ethiopia. The economy of Ethiopia faced erotic food inflation while non-food inflation relatively stable. Food inflation was 15.1 percent in 2006 and it reached 57.4 percent in 2008, however it was quite relatively low in 2009 at 36.4 percent. Poor household of Ethiopia spend more than 55 percent of their income on food items rise in the prices of basic need (food) adversely affect their living standard. Researchers concluded that money supply, exchange rate, global prices, fertilizer prices are the factors responsible for food inflation.

M. Maqsood Azeem et al (2012) expressed the causes of wheat price inflation in Pakistan. They used explanatory variables previous year prices, oil prices, money supply and wheat support prices for the analysis on time series data from 1981 to 2010. Their finding showed that money supply is insignificant to wheat price while all other variables are significant.

M. Nadim Hanif (2012) conducted a study from the state bank of Pakistan platform on food inflation in Pakistan. The researcher examined the data from January 1992 to January 2012.Finding of the study was the world food prices shocks highly affect the prices of food in Pakistan during last two decade other factors like rains and floods also create supply shocks which create high inflation in food sector. He also pointed out that majority of the firms in Pakistan is using old strategies for setting the prices that is big reason that lowering the prices do not sharply transmit to consumer.

Other national studies on food inflation as Abdul Aleem K.(2007) observed that depreciation in exchange rate and government borrowing is creating food inflation in Pakistan while wheat support price is insignificant to food inflation. Theresa Thompson Chaudhry et al (2008) 
studied the impact of rising food and oil prices on the poverty of Pakistan. Their finding showed that rising prices of oil and food have a huge impact on the poverty of Pakistan. World food program (2009) reported that that 30 percent of purchasing power of labor decreases in term of wheat flour after 2007 because of rising food prices. Farooq et al (2013) traced out that money supply, GDP and non-development expenditures of government are positively correlated with the food prices in Pakistan. Salman A.J.(2013) examined that money supply, GDP growth and food export is responsible for food inflation in Pakistan while credit distributed to agriculture sector is negatively correlated with food prices.

\section{MOdEL BUILDING}

Present study examine the cost push and demand pull variables causing food inflation in Pakistan. For this purpose we included the factors (cost push and demand pull) as in following equation form:

LFPI $=\beta 0+\beta 1 \mathrm{LM} 2 \mathrm{i}+\beta 2 \mathrm{LERi}+\beta 3 \mathrm{LPGDPi}+\beta 4 \mathrm{LFAIDi}+\beta 5 \mathrm{LFRPi}+\beta 6 \mathrm{LFUPi}+\mu \mathrm{i}$

\section{Dependent Variable:}

LFPI $=$ LN of food price index based on 1980

\section{Explanatory Variables:}

LM2 = LN of Money Supply LER $=$ LN of Exchange Rate

LPGDP $=$ LN of Per-Capita GDPLFAID $=$ LN of Foreign Aid

LFRP $=$ LN of Fertilizer price LFUP $=$ LN of Fuel Prices

$\beta^{\prime} S=$ Slope of Coefficient $\mu=$ Error Term

\section{DatA AND VARIABLES}

\section{Sources of Data}

Annual data for all variables is for the period of 1980-2013. Data of the food price inflation , money supply ,fuel prices, fertilizer prices and foreign aid has been taken from the Government of Pakistan(Pakistan economics survey) while data of Per capita income and exchange rate has been taken from the world development indicators. Variables are in natural logarithm form so, estimation give direct elasticites.

\section{Description of Variables}

This portion explains the variables and their expected signs.

Money Supply (M2): M2 is explanatory variable used in the study. M2 defined as the money ,quasi money included time, saving, foreign and demand deposits of private sectors other than government ( IMF ,IFS: line no 34,35,WDI 2013).According to monetarist theory , money supply in economy is directly influence the prices. Rise in Money supply due to increase the credit to government by SBP lead to high monetary growth which influence the overall inflation especially food prices. If we consider money supply is equal to money demand than higher money demanded for food items lead the prices of food to rise. Thus, we expect a direct relation between money supply (M2) and food inflation.

Exchange Rate (ER): Exchange rate is a variable that effect the food prices in two ways (i) Depreciation in the exchange rate increase the price of imported inputs as pesticides, fertilizers chemical, and seeds and it directly affect the prices of finished products that are being imported as pulses, palm oils, (ii) Depreciation in exchange rate also cause to increase the import price of oil product (petrol, diesel) which increase the transportation cost of agricultural products and it is being charged from the prices of food items. Thus we expect that exchange rate is associated with food inflation, depreciation in exchange rate cause to increase in food prices. 
Per Capita GDP (PGDP): We included the per capita GDP as a factor of rising food prices because it is proxy for the dietary plan of consumers. Higher per capita income leads to change in dietary habits e.g., consumers prefer to eat at restaurants and hotels which lead to increase in the demand for meat and dairy products that require a heavy quantity of grains for livestock and so, cause to decrease the supply of grains for consumers. It also cause to increase the price of grain and it made costly for consumer to fulfill the malnutrition. Thus, we expect that higher PCI lead to increase in food prices in this way PGDP will positively correlated with food inflation.

Foreign Aid (FAID): Foreign aid also affect the domestic prices being a agriculture economy it affect the agriculture market also which results in food inflation .Aid transfer to Pakistan increase the money supply and this aid is not utilizing on productive project. The money spend on nonproductive projects have no positive effect on the output hence this increase the prices of local commodities especially it transmit in the prices of foods.

Fertilizer Prices (FRP): Fertilizer is an important input for agriculture production. Increase in the prices of fertilizers result the less use of fertilizers by farmers which leads to low production and it further cause to increase the prices. Secondly high fertilizers prices increases the production cost of food items which is being charged from the final products. Thus, we expect the prices of fertilizers and food prices are positively correlated.

Fuel prices (FUPI): Energy prices included the diesel and other petroleum products also influence the food prices. A rise in the price of petroleum products leads to increase in transportation cost and other input cost as uses of tractors and water supplier machinery. Higher prices of petroleum products made expensive of the machinery which further charged from the output which is a key variable to increase the food inflation. Thus, we expect the energy prices are positively related with the food prices. We use the fuel price index as proxy to energy prices due to non-availability of data from 1980 of petrol and diesel.

\section{Descriptive Analysis of Data}

Trendy of the diagrams, Figure 1(a) and figure 1(b) shows the graphical relation between money supply and food prices, Money supply growth and food price inflation respectively. The correlation between money supply and food prices is high it is 98 percent but if we look carefully at the 1(b) we see at some period in the graph where money supply and food price inflation is negatively correlated which indicate that at some time interval money supply is negatively correlated with food inflation may be in that period the increase in money supply invest in the productive or technological purpose which further increase the supply of food and push down the prices on the food .

Figure 1 (a): Food Prices and Money Supply

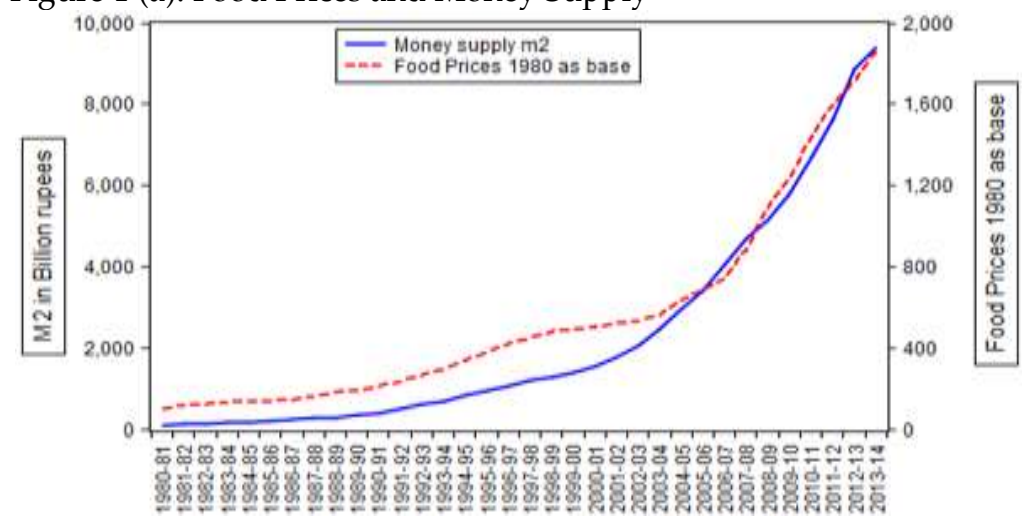

Source: Authors estimation based on data from Economic survey of Pakistan from 1980 to 2013 
Figure 1(b): Food Price Inflation and Money Supply Growth

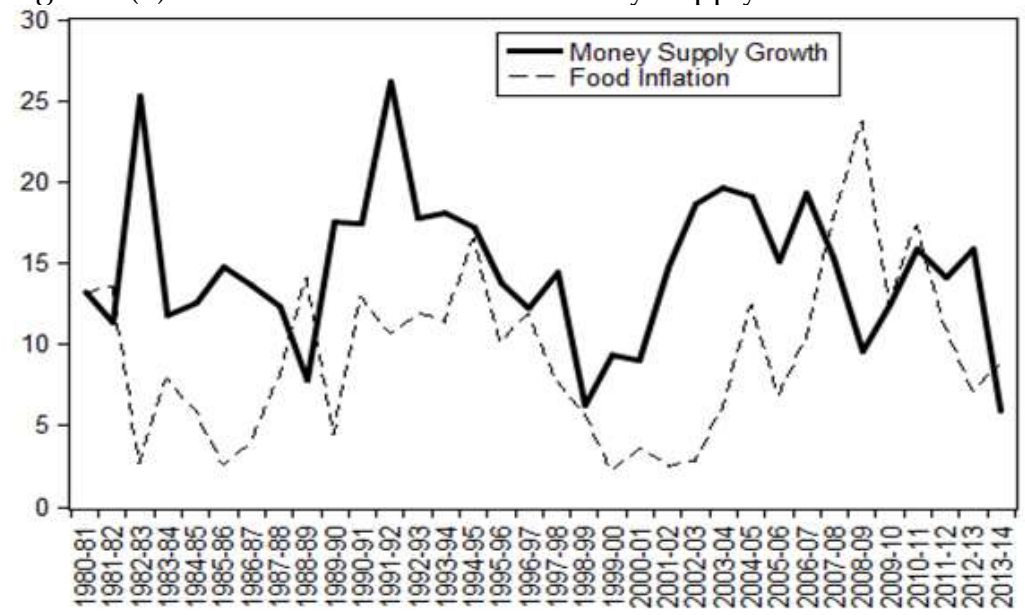

Source: Authors estimation based on data from Economic survey of Pakistan from 1980 to 2013

Figure2 shows the trends in exchange rate and food prices. Exchange rate shows the dollar conversion into local currency rupees. It is expected that these two highly negatively correlated with each other. Because when value of rupees in term of dollar decrease it will increase the cost of imported food items pulses, cooking oil as well as other cost also increase like fuel prices, fertilizers chemical and pesticides.

Figure 2: Exchange rate and Food prices

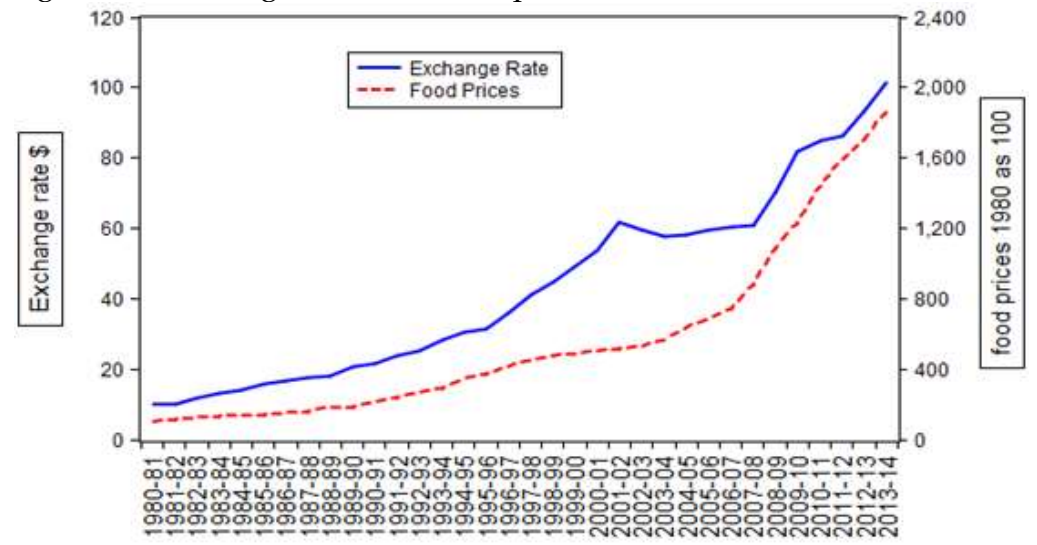

Source: Authors estimation based on data from Economic Survey of Pakistan from 1980 to 2013

Figure 3 shows the trend of foreign aid and food prices. It shows the strong relation from 1980 to 1999 these two variables are strongly associated while later on after the 2000 foreign aid decrease in some years but food inflation is continuously increasing. The correlation between two variables is high 89 percent. The reason may be that the foreign aid in Pakistan is not invested in productive purpose when it is not invested in productive purpose it only increase the money supply which create inflation and Pakistan is agrarian economy and a developing nation so, it hurt the agriculture sector and the resulting effect on the prices of food. 
Figure 3: Foreign Aid and Food prices

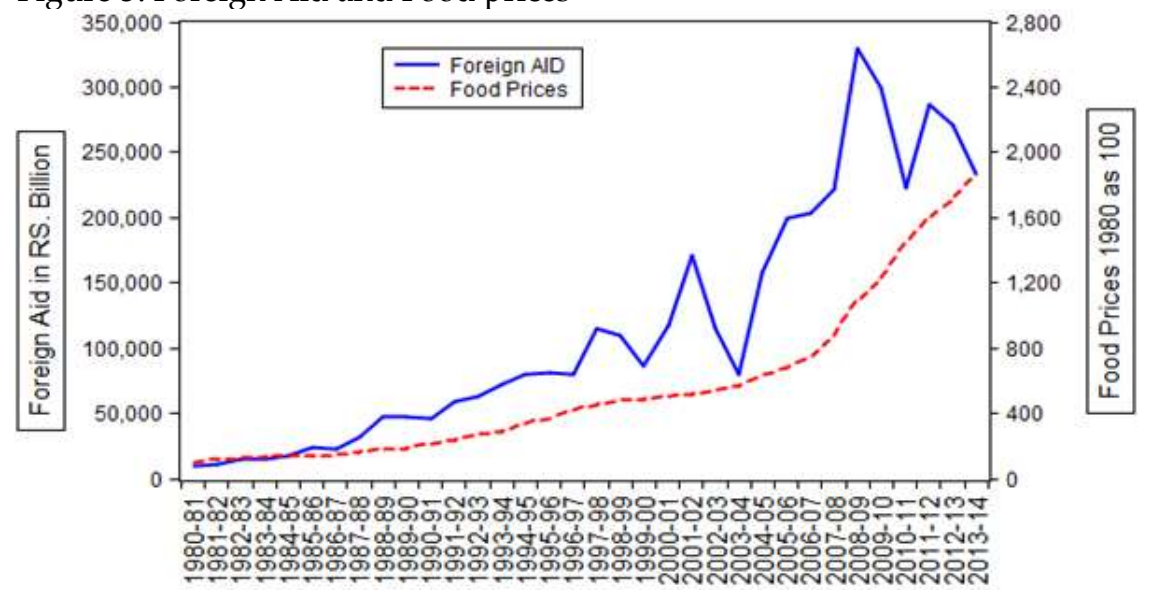

Source: Authors estimation based on data from Economic Survey of Pakistan from 1980 to 2013

Trendy of the diagrams , Figure 4(a) and figure 4 (b) shows the graphical relation between per capita GDP and food prices and Per capita GDP growth and food inflation respectively. The correlation between per capita GDP and food prices is high it is 99 percent but if we look carefully at the figure $4(\mathrm{~b})$ we see at some period in the graph where per capita GDP and food inflation is negatively correlated. The correlation between per capita GDP and food inflation is positive 6 percent.

Figure 4(a) : Per Capita GDP and Food Prices

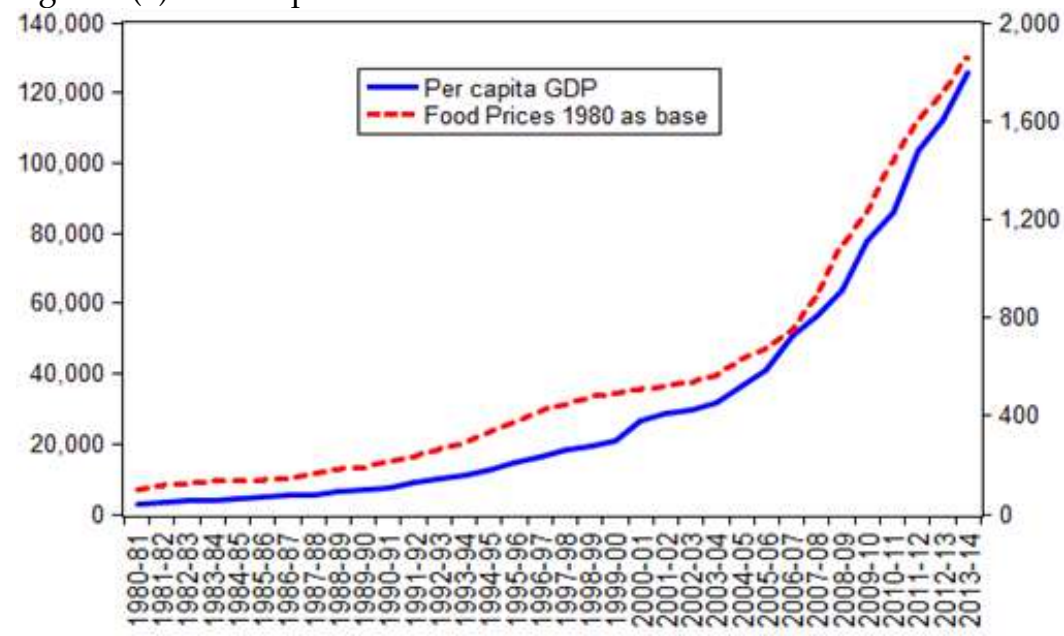

Source: Authors estimation based on data from World Development Indicators 
Figure 4(b): Per Capita GDP Growth and Food Inflation

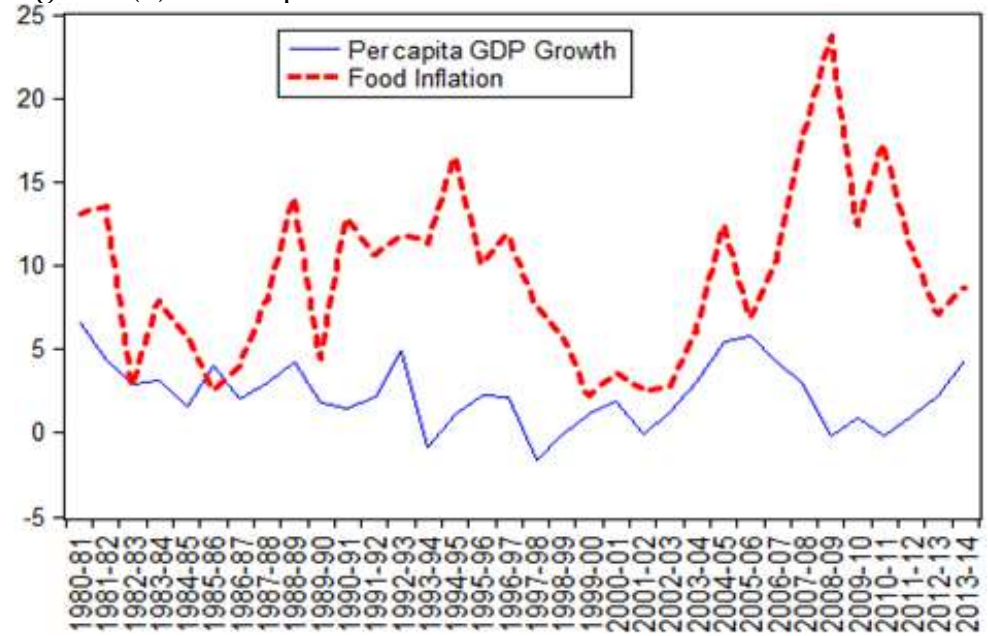

Source: Authors estimation based on data from World Development Indicators

Figure 5 shows the fertilizer prices and food prices, a positive long run association between two variables. The correlation between these two variables is 84 percent and positive. In recent years food prices are increasing rapidly especially in 2008 while there is little control on the prices of fertilizers. The upward trend in fertilizer prices increase the cost of production which further push up the prices of food but if we carefully examine the graph after 2008 there is slow increase in the prices of fertilizers but food prices rise sharply after 2008.

Figure 5: Fertilizer prices and Food prices

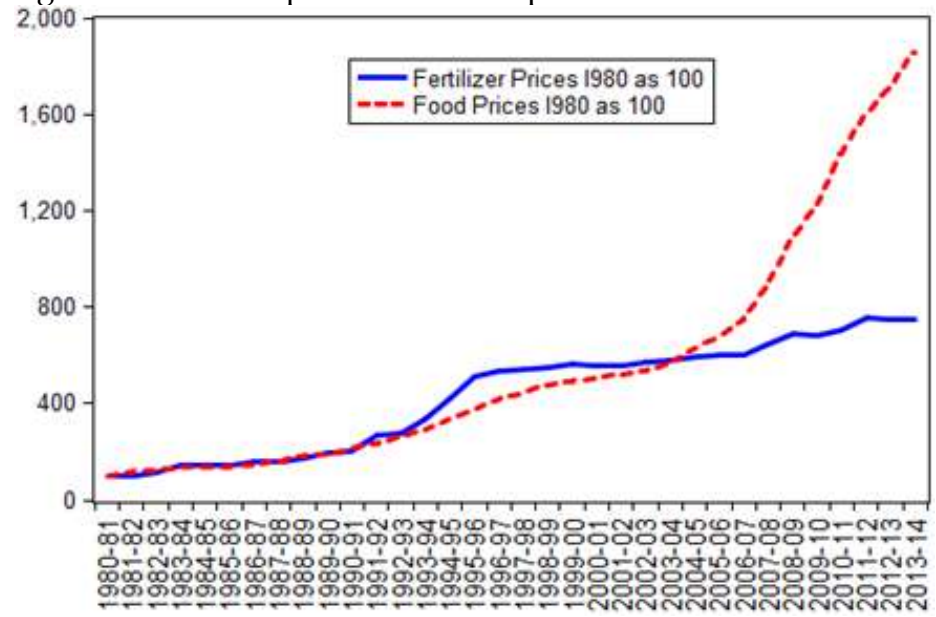

Source: Authors estimation based on data from Economic Survey of Pakistan from 1980 to 2013

Figure 6 shows the fuel prices and food prices, it shows a significant, positive correlation between two variables. The correlation between two variables is 99 percent which shows a strong relation between variables. This index is used as proxy to the energy prices which indicate that as the prices of energy goes up it also push up the prices of food also. 
Figure 6: Fuel prices and Food prices

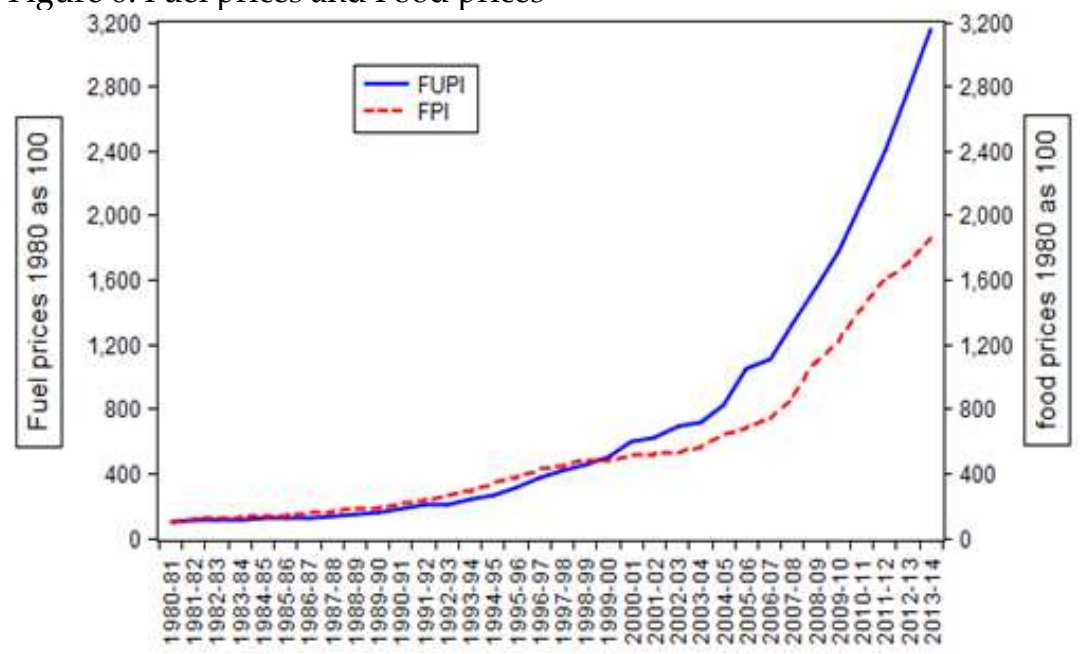

Source: Authors estimation based on data from Economic Survey of Pakistan from 1980 to 2013

\section{ANALYTICAL FRAMEWORK}

We are interested in cost push and demand pull variables affecting the food prices in long run and short run, we employed ADF unit root test, Johansen's co-integration, and VECM for the results.

\section{Augmented Dickey Fuller Test (ADFT)}

The stationary of data or order of integrated is checked by ADF unit root test. The hypotheses of the checking are:

Null hypothesis: $\mathrm{H} 0=0$ (Time series is not stationary or It has a unit root)

Alternative hypothesis: $\mathrm{H} 1<0$ (Time series is stationary)

If we apply ADF test at level if null hypothesis is rejected we consider that variable is stationary at level but if null hypothesis is accepted then we apply the first difference to check the null hypothesis again the equation after adding the lag values transform to the following

$$
\Delta \mathrm{Yt}=\beta 1+\beta 2 \mathrm{t}+\delta \mathrm{iYt}-1+\Sigma \alpha 1 \Delta \mathrm{Yt}-1+\epsilon \mathrm{t}
$$

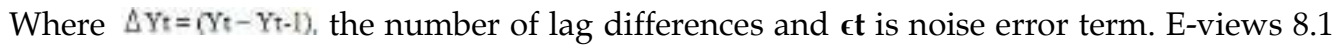
has an option to select the lag length automatically based on AIC and SIC.

\section{Information Criteria (Lag length Selection)}

Model selection is based on different information criterion. The number of repressors added to the model is checked by the following different criteria:

Akaik information Criterion $(\mathrm{AIC})=\ln \mathrm{AIC}=(2 \mathrm{k} / \mathrm{n})+\ln (\mathrm{RSS} / \mathrm{n})$

Schwarz information criterion $(\mathrm{SIC})=\ln S \mathrm{IC}=\mathrm{k} / \mathrm{n} \ln \mathrm{n}+\ln (\mathrm{RSS} / \mathrm{n})$

\section{Johansen co-integration Technique}

Johansen and Juselius (1990) have introduced new method of co-integration to examine the short and long run relation. Suppose we have three variables $Y, X$ and $W$. Now, using matrix notation for $\mathrm{Zt}=[\mathrm{Tt}, \mathrm{Xt}, \mathrm{Wt}]$ 
$\mathrm{Zt}=\mathrm{A} 1 \mathrm{Z} \mathrm{t}-1+\mathrm{A} 2 \mathrm{Z} \mathrm{t}-2+\mathrm{A} 3 \mathrm{Zt}-3$ $+\mu \mathrm{t}$

This equation can be written in vector error correction model as follows;

$$
\Delta \mathrm{Zt}=\mathrm{r} 1 \Delta \mathrm{Zt}-1+\mathrm{r} 2 \Delta \mathrm{Zt}-2+\mathrm{r} 3 \Delta \mathrm{Zt}-3 \quad \ldots \ldots \ldots+\Pi \mathrm{Z} \mathrm{t}-1+\mu \mathrm{t}
$$

Where ri $=(1-\mathrm{A} 1-\mathrm{A} 2-\mathrm{A} 3 \ldots .$.$) and \Pi=-(1-1-\mathrm{A} 1-\mathrm{A} 2-\mathrm{A} 3 \ldots .$.$) Here we need to analysis the$ $3 \times 3$ matrix because we suppose there is three variables in our model. In verity $\Pi=\alpha \beta$ where $\alpha$ will denote to the speed of adjustment while $\beta$ is long run matrix of coefficient.

Johansen and juselius (1990) have proposed following steps for good results.

- For Johansen test all variables must be co-integrated at first difference.

- The lag length of the model must be based on AIC and QIC using VAR model.

- Test based on the two approaches maximum Eigen value statistics and trace statistics which clearly shows the result of co-integrated.

\section{Vector Error Correction Model (VECM)}

A series that is co-integrated and non-stationary transform to stationary after difference. The VECM shows the long and short run co-integration relationships. The co-integrated term widely known as error correction term which show the adjustment percentage to equilibrium?

$\square L F P I=\left(\begin{array}{l}a_{0}+\sum_{j=1}^{q} a_{1} \square L F P I_{t-1}+\sum_{j=0}^{q} a_{2} \square L F R P I_{t-1}+\sum_{j=0}^{q} a_{3} \square L F U P I_{t-1}+\sum_{j=0}^{q} a_{4} \square L F A I D_{t-1} \\ +\sum_{j=0}^{q} a_{5} \square L P G D P_{t-1}+\sum_{j=0}^{q} a_{6} \square L E R_{t-1}+\sum_{j=0}^{q} a_{5} \square L P G D P_{t-1}+\sum_{j=0}^{q} a_{6} \square L M 2_{t-1}+\psi_{1} E C M_{t-1}+\varepsilon_{1 t}\end{array}\right)$

Where $\Delta$ denote for the difference, $\mathrm{q}$ stands for the lag length, alphas are parameters, error correction term is denoted by $\psi$ and finally the error correction term is representative by $\varepsilon$.

\section{EMPIRICAL RESULTS}

The results in Table1 presents that variables (FPI, M2, FAID, PGDP,FUPI,FRPI and Exchange rate ) are not stationary at level as they are integrated of order I(1) and found stationary at first difference. As the variables are integrated at same order this is why we will use Johansen approach for further analysis.

Table 1: Augmented Dickey Fuller Test for unit root

\begin{tabular}{|l|l|l|l|l|l|}
\hline \multirow{2}{*}{ Variables } & At Level & \multicolumn{2}{l|}{ At First Difference } & \multirow{2}{*}{ Conclusion } \\
\cline { 2 - 5 } & $\mathbf{t}$ - statistics & Probability & $\mathbf{t}$ - statistics & Probability & \\
\hline LFPI & 0.739915 & 0.9906 & -4.740668 & 0.0009 & $\mathrm{I}(1)$ \\
\hline LFRPI & -2.333945 & 0.1678 & -3.932193 & 0.0050 & $\mathrm{I}(1)$ \\
\hline LFUPI & 2.431646 & 0.9999 & -6.277311 & 0.0000 & $\mathrm{I}(1)$ \\
\hline LAID & -2.556003 & 0.1128 & -8.092894 & 0.0000 & $\mathrm{I}(1)$ \\
\hline LPGDP & 1.186920 & 0.9974 & -5.942824 & 0.0000 & $\mathrm{I}(1)$ \\
\hline LER & 2.410780 & 0.1483 & -4.822300 & 0.0005 & $\mathrm{I}(1)$ \\
\hline LM2 & -1.045514 & 0.7246 & -4.005583 & 0.0041 & $\mathrm{I}(1)$ \\
\hline
\end{tabular}

The result showed that all variables food prices(LFPI), fertilizer prices(FRPI), fuel prices(FUPI) , foreign aid(LAID), per capita income (LPGDP), exchange rate (LER), and money supply ( LM2) had unit root at level means they are not stationary at level .The first difference of food prices. This is the case of most of developing countries that their data not stationary at level (Malkiuk, 2007). The first difference of all the variables made them stationary. 


\section{Co-integrated vectors}

Examine the long run relationship between the variables it needs to find the co-integrated vectors. If there is no long run association between the variables then it need to find short term relations with VAR model but it there is long run association then VECM will use for further procedure. The study founded the number of co-integrated equation using Johansen', s cointegrated technique. Trace statistics in table 2 rejected the null hypothesis that there is no cointegrated equation in model (None), there is one co-integrated vector (At most 1), there is at most two co-integrated vector (At most 2), there is three co-integrated vactor (At most 3 ), The result showed that there are four co-integrated equations in the concern variables. Same, the result of Eigen value statistics shown in table 3 which also confirm the trace statistics results that there are four co-integration equation for the analysis of long run estimations which shows the high degree of association of the variables used in the current study.

Table 2: Trace Statistics

\begin{tabular}{|c|c|c|c|c|}
\hline \multicolumn{5}{|c|}{ Date: $02 / 12 / 15$ Time: $17: 42$} \\
\hline \multicolumn{5}{|c|}{ Sample (adjusted): 19822013} \\
\hline \multicolumn{5}{|c|}{ Included observations: 32 after adjustments } \\
\hline \multicolumn{5}{|c|}{ Trend assumption: Linear deterministic trend } \\
\hline \multicolumn{5}{|c|}{ Series: LFPI LAID LER LFRP LFUPI LM2 LPGDP } \\
\hline \multicolumn{5}{|c|}{ Lags interval (in first differences): 1 to 1} \\
\hline \multicolumn{5}{|c|}{ Unrestricted Cointegration Rank Test (Trace) } \\
\hline Hypothesized & & Trace & 0.05 & \\
\hline No. of CE(s) & Eigenvalue & Statistic & Critical Value & Prob. ${ }^{* *}$ \\
\hline None * & 0.852451 & 200.7690 & 125.6154 & 0.0000 \\
\hline At most $1 *$ & 0.760089 & 139.5339 & 95.75366 & 0.0000 \\
\hline At most $2 *$ & 0.727099 & 93.85433 & 69.81889 & 0.0002 \\
\hline At most $3 *$ & 0.578266 & 52.29767 & 47.85613 & 0.0181 \\
\hline At most 4 & 0.384211 & 24.66952 & 29.79707 & 0.1736 \\
\hline At most 5 & 0.245480 & 9.154283 & 15.49471 & 0.3513 \\
\hline At most 6 & 0.004388 & 0.140714 & 3.841466 & 0.7076 \\
\hline \multicolumn{5}{|c|}{ Trace test indicates 4 cointegrating eqn(s) at the 0.05 level } \\
\hline \multicolumn{5}{|c|}{ * denotes rejection of the hypothesis at the 0.05 level } \\
\hline \multicolumn{4}{|c|}{ **MacKinnon-Haug-Michelis (1999) p-values } & \\
\hline
\end{tabular}

Table3: Eigen value Statistics

\begin{tabular}{|c|c|c|c|c|}
\hline \multicolumn{5}{|c|}{ Unrestricted Cointegration Rank Test (Maximum Eigenvalue) } \\
\hline Hypothesized & & Max-Eigen & 0.05 & \\
\hline No. of CE(s) & Eigenvalue & Statistic & Critical Value & Prob. ${ }^{* *}$ \\
\hline None* & 0.852451 & 61.23508 & 46.23142 & 0.0007 \\
\hline At most $1 *$ & 0.760089 & 45.67961 & 40.07757 & 0.0106 \\
\hline At most $2 *$ & 0.727099 & 41.55666 & 33.87687 & 0.0050 \\
\hline At most 3 * & 0.578266 & 27.62815 & 27.58434 & 0.0494 \\
\hline At most 4 & 0.384211 & 15.51524 & 21.13162 & 0.2544 \\
\hline At most 5 & 0.245480 & 9.013569 & 14.26460 & 0.2850 \\
\hline At most 6 & 0.004388 & 0.140714 & 3.841466 & 0.7076 \\
\hline \multicolumn{5}{|c|}{ Max-eigenvalue test indicates 4 cointegrating eqn(s) at the 0.05 level } \\
\hline \multicolumn{5}{|c|}{ * denotes rejection of the hypothesis at the 0.05 level } \\
\hline \multicolumn{4}{|c|}{ **MacKinnon-Haug-Michelis (1999) p-values } & \\
\hline
\end{tabular}

\section{Long Run Estimates}


The long run estimation of food price inflation is in table. First column of the table show the name of variables, second coefficient, third standard error, fourth t-statistics and finally fifth column show the significant and insignificancy of the variables.

Table: 4: Long run relationships

\begin{tabular}{|l|l|l|l|l|}
\hline Variables & Coefficients & Standard Errors & T - statistics & Conclusion \\
\hline LFRPI & 0.37122 & 0.02549 & -14.5654 & Significant \\
\hline LFUPI & 0.781282 & 0.08196 & -9.53243 & Significant \\
\hline LAID & 0.079387 & 0.01828 & -4.34314 & Significant \\
\hline LPGDP & 0.761671 & 0.10956 & 6.95227 & Significant \\
\hline LER & -1.613325 & 0.04716 & 34.2061 & Significant \\
\hline LM2 & 1.406097 & 0.04488 & -31.3286 & Significant \\
\hline C & -1.447183 & ------ & ------- & -------- \\
\hline
\end{tabular}

The result shows that both demand pull and cost push variables included in the model is significant to increasing food prices in Pakistan. The coefficient of log-log model are shows is the table. The cost push variable fertilizer prices shows positive sign and significant this is according to the cost push theory that increase in the input prices or cost of production directly affect the prices of commodities and create food inflation. Our result is consistent with previous finding of Haji and Gelaw (2012), M .Abdullah (2009). Second cost push variable fuel price index which is used as proxy to the petrol and diesel prices is also positively related with food prices, this is also according to cost push theory and in the case of Pakistan it is also proved that rising prices of fuel result in high transportation cost that transfer the food items to consumers that cost is added in the prices of food and create food inflation. Our finding is consistent with the previous investigation of Masood and Azeem (2012), Hamid Salman and Faisal Aftab (2013).

Similarly demand pull variables foreign aid is also significant to food inflation the coefficient shows that 1 percent rise in foreign aid increases the food inflation by 0.079387 percent. Because in case of developing countries like Pakistan foreign aid is not utilize on the productive purpose . it only cause to increase in supply of money which indirectly effect on the demand and result in rise demand and create demand pull inflation. Same relation was established in Malikuk (2007).

Per capita gross domestic production (LPGDP) has positive relation with food prices it is according to theory that as the per capita income increases in an economy as the living standard of people improve they change their dietary habits and prefer to restaurant and out of home food which affect the demand for luxury food and it cause to increase the overall prices of food in economy. The coefficient showed 1 percent increase in per capita GDP increase the food inflation by 0.761671 percent. Our result is consistent with the previous finding of M. Abdullah and Rukhsana Kalim (2012), Muhammad Masood (2012), Saira Anam et al (2014).

With regard to exchange rate it is being inversely related with the food prices.The sign of coefficient is negative and it is also significant. One percent depreciation in exchange rate decrease the food inflation -1.613325. The depreciation in exchange rate make the food items of Pakistan relatively cheaper and this further cause to increase the exports. Rise in the exports make the investment opportunities in the agriculture sector which result to increase in the production that decrease the prices of food. Our finding is consistent with the previous finding Hamid Salman and Faisal Aftab (2013) but contradiction with the Qazi Masood (2014). 
In the same manner the study includes the money supply variable which also proves the positive effect on the food price index. If money supply increases by one percent it increases the food inflation by 1.406097 percent. It means it reject the claim that food inflation in Pakistan is not monetary phenomenon. The government prints the extra money (seignorage) from state Bank of Pakistan to finance its deficit and that wasted on the nonproductive purpose which only results in the rising prices in the economy of Pakistan. Our finding is consistent with the previous finding Rana Ejaz (2007) and M. Abdullah (2009).

\section{Vector Error Correction Model (Short run Results)}

Vector error correction model is used to examine the short term relation and to examine the speed of adjustment broadly called error correction term. The overall short run result is present in the table 5, the sign of coefficient of error correction term is negative which shows the speed of adjustment towards equilibrium due to short run shocks of proceeding period. The value of coefficient is (0.150023) which denoted the equilibrium speed of 15 percent .Since, we used annual data, we assume it take about seven years to restore the equilibrium .Result also shows that food inflation in Pakistan is long run phenomenon. In short run only fuel prices are the significant to food prices because as the prices of fuel increase its immediately increase the transportation cost which push up the prices in short run also while all others variables are not significant in short run.

Table 5: VECM (Short run relationships)

\begin{tabular}{|c|c|c|c|}
\hline Variables & Coefficients & Standard errors & T - statistics \\
\hline Error Correction Term & -0.150023 & 0.06143 & -2.44218 \\
\hline D(LFPI(-1)) & 0.348313 & 0.21393 & 1.62815 \\
\hline D(LFPI(-2)) & -0.232924 & 0.22213 & -1.04857 \\
\hline D(LFRPI(-1)) & 0.145703 & 0.11121 & 1.31016 \\
\hline D(LFRPI(-2)) & 0.027963 & 0.10762 & 0.25983 \\
\hline D(LFUPI(-1)) & -0.257663 & 0.14960 & -1.72229 \\
\hline D(LFUPI(-2)) & -0.461462 & 0.14885 & -3.10010 \\
\hline $\mathrm{D}(\mathrm{LAID}(-1))$ & -0.058393 & 0.03515 & -1.66126 \\
\hline $\mathrm{D}(\mathrm{LAID}(-2))$ & 0.029264 & 0.03026 & 0.96697 \\
\hline D(LPGDP(-1)) & 0.247828 & 0.16869 & 1.46909 \\
\hline D(LPGDP(-2)) & 0.013414 & 0.15018 & 0.08932 \\
\hline $\mathrm{D}(\operatorname{LER}(-1))$ & 0.345052 & 0.19877 & 1.73597 \\
\hline $\mathrm{D}(\operatorname{LER}(-2))$ & -0.010242 & 0.16938 & 0.06047 \\
\hline D(LM2(-1)) & 0.271151 & 0.19890 & 1.36325 \\
\hline $\mathrm{D}(\mathrm{LM} 2(-2))$ & -0.220594 & 0.25826 & -0.85416 \\
\hline Constant & 0.087360 & 0.05796 & 1.50730 \\
\hline \multicolumn{4}{|c|}{\begin{tabular}{|lccc} 
R-squared & $0.772203 F-s t a t i s t i c$ & 3.389878 \\
Adj. R-squared & 0.544406 & Prob. (F-stats) & 0.05 \\
\end{tabular}} \\
\hline
\end{tabular}

\section{Conclusion}

Food price inflation emerges as a main challenge in the economy of Pakistan as well as on global level from the last few years. Sharpe Rising in prices of food has increasing the cost of living which hurts the poor, because they spend more than 60 percent of their income on food. This study investigates the factors affecting the food prices in Pakistan. Time series data from 1980 to 2013 of relevant variables included the cost push variables fuel prices, fertilizer prices and demand pull monetary variables money supply, exchange rate, foreign aid and per capita 
GDP as the determinants of food inflation in Pakistan. We applied ADF test, from the test we found all variables are integrated of order one and the guideline is that if all variables are not stationary at level but stationary at first difference then Johansen co-integration technique must use for further estimation. So, accordingly we use Johansen technique to examine the long run relation we find four co-integrated vectors which denote that variables in the study have a strong long term relations. Further we used vector error correction model. Result showed that all variable except exchange rate are positively related with the food prices. High prices of fuel lead to high transportation cost which push up the food prices. Money supply, foreign aid, and per capita GDP have long run significant relationship with food prices. Moreover, the vector error correction model shows the negative sign with the ECT term which indicate the speed of adjustment toward long run equilibrium. However, we did not touch the underline factors which also cause to increase food inflation such as smuggling and other political factors which are the limitations of study.

\section{POLICY IMPLICATIONS}

Empirical result show that both demand pull and cost push variable include in the model are significant to food inflation. Fuel prices are significant to food inflation both in long run and short run .The government should invest in roads especially areas of poor infrastructure should develop new roads from villages to agriculture markets in cities so the distance reduce to minimize the transportation cost because fuel prices on international level are beyond the control of any local government so it is need a better strategy to minimize the cost. Further government should encourage private sector to invest in fertilizers and pesticides and also make proper arrangement to check the quality produce by private sector. This will helpful to control the food inflation in two ways first the cost of input as fertilizers and pesticides decrease which further decrease the output prices second farmers will use the accurate quantity of these which will result to increase the production.

According to this study the per capita GDP is also a factor contributing to food inflation the reason is that the share of agriculture to GDP is falling rapidly and the share of manufacturing and services in GDP is increasing. A proper policy should be needed for this critical condition, credit faculty to agriculture sector must be encourage by private and government sector and water shortage problem must also be considered and solved by new dams. Food inflation in Pakistan also proved a monetary phenomenon according to this study .The government must search for income resources to fill its budget deficit instead of printing money and those institutes must be privatize in which government have to face heavy losses since a many years. So, the budget deficit decrease this will help to control the money supply which will helpful to control the prices. Based on the results, the present study suggested that government should adopt effective monetary and fiscal policy to control the alarming condition of food prices. A long term measures are needed to implement and checked them properly. Government should invest in the research and development in agriculture sector and make a proper system of communication and guidance for the farmers. Further foreign aid must be used for productive purposes. These aids must invest to improve the infrastructure and energy sector to reduce the prices.

\section{REFERENCES}

Ahsan, Henna; Iftikhar, Zainab; Kemal, M. Ali(2010) "The Determinants of Food Prices in Pakistan" The Lahore Journal of Economics , Vol. 17, No. 1

Ashley C., David G., Josh Lee, Marcus M., and Luc Noiset (2011) "The Rise of Food Prices and the Fall of Nations" working paper by Kennesaw State University. 
Awan, A.G. \& Waqas Ahmed (2014) "Role of Policies in Economic Growth: A case Study of China's Economic Growth" Global Journal of Arts, Humanities and Social Sciences, Vol.2, No.8 (October,2014).

Awan, A.G. (2014) "Brazil's Innovative Anti-poverty and Inequality Model" American Journal of Trade and Policy, Vol 1 No.3.

Awan, A.G., Nasir Nadeem,\& Beenish Rashid (2015) "Factors Effecting The Rural Women Labour Supply in Agriculture Sector", Developing Country Studies, Vol 5, No.1.

Awan, AG \& Abdul Jabbar (2014) "The Determinants of Capital Inflow in Developing Countries with special reference to Pakistan", Developing country Studies, Vol.4, No.12.

Axel S. and Mohsin S.K.(2006) "Inflation in Pakistan: Money or Wheat?" International Monetary Fund : IMF working paper NO WP/06/60, SBP Research Bulltitioan Vol 2, P-212-234

Farooq A., Hassan Raza et al( 2013) " Determinant of Inflation in Pakistan: An Econometrics Analysis,Using Johansen Co Integration Approach"European Journal of Business and Management ISSN 2222-2839(Online)Vol.5, No.30, 2013

Gujrati, D.N.and Dawn C.P. (2007).Basic Econometrics. United States Military Academy. $5^{\text {th }}$ edition.

Hamid S.,Faisal A., and R.N.Lodhi (2014) " Macroeconomic Variables and Rising Food Prices: Empirical Evidence from Pakistan" IBT Journal of Business Studies (Formerly Journal of Management \& Social Sciences) Vol. 10, No. 1, [66-82]

M. Masood, A., Samreen, M. and Khalid, M. (2012)“ An Empirical Analysis of Factors Affecting Food (Wheat) Inflation in Pakistan" Pak. J. Agri. Sci., Vol. 49(2), 199-203

M. Nadim H. (2012) "A Note on Food Inflation in Pakistan" Pakistan Economic and Social Review Volume 50, No. 2 (Winter 2012), pp. 183-206

M.Aslam Ch. And Naveed A.(1995) "Money Supply, Deficit, and Inflationin Pakistan"The Pakistan Development Review34 : 4 Part III pp. 945-956

Paul A. S., and William D.N.(2014) "Economics", 19th Edition McGraw-Hill Irwin

Philips C. A. (2011) issue report "What's Driving Food Prices in 2011"Farm Foundation of US. Online at: www.farmfoundation.org

Quentin Wodon and Hassan Zaman (2008)“Rising Food Prices in Sub-Saharan Africa: Poverty Impact and Policy Responses" The World Bank Human Development Network Policy ResearchWorking Paper 4738

Sadiq Ahmed(2008) “Global Food Price Inflation Implications for South Asia, Policy Reactions, and Future Challenges" Policy Research Working Paper 4796

Salman. A. J. and Adnan Ali Shahzad (2013) "Determinants of High Food Prices: The case of Pakistan" Pakistan Economic and Social Review 51(01) pp. 93-107.

Theresa Thompson, C. and Azam A, Chaudhry (2008) "The Effects of Rising Food and Fuel Costs on Poverty in Pakistan" The Lahore Journal of Economics Special Edition pp. 117-138

WFP, Marketing Price monitoring System Labeled "Pakistan Food Security Market Price Monitoring" Bulletin-15October-December2009

Xavier Irz, Jyrki Niemi and Liu Xing (2012) "Determinants of food price inflation in Finland" MaataloustieteenPäivät 2012 online at:www.smts.fi 


\section{Publish Online and Print Version Both}

ISSN Online: 2312-203X 